\title{
Inflammatory Bowel Disease etiology: current knowledge
}

https://doi.org/10.1515/pteridines-2018-0020

received December 17, 2018; accepted December 21, 2018.

Abstract: Non-specific inflammatory bowel diseases (IBD) include Crohn's disease (CD) and ulcerative colitis (UC). Both diseases are characterized by chronic inflammation of unclear etiology. The inflammatory bowel diseases incidence is continuously observed to rise.

Colon inflammatory response is a physiological process which occurrence is indispensable as an organisms' defense reaction. The inflammation may be caused by internal factors associated with body's cells as well as external factors, such as infections and exposition for inflammatory agents. Until recently, IBD have been classified as autoimmune diseases, today they seem to be associated with gut barrier disorders or dysbiosis. Factors that predispose to inflammatory bowel diseases include: genetic factors, dysbiosis and so called western-type diet, natural componentssuch as gluten andlactose. In addition, the development of the disease is favored by: cigarette smoking, phosphate, nanomolecules, sodium chloride, emulgents, carrageenan, carboxymethylcellulose, pollution, maltodextrin. IBD affects whole the body, causing serious medical consequences. Symptoms like anxiety and chronic stress, that occur commonly, can lead to depressive disorders. Quantitative and qualitative dietary deficiency caused by absorption disorders, may promote the occurrence of osteoporosis and osteopenia. In addition, dysbiosis coexisting with alterations in intestinal permeability can lead to the development of nonalcoholic fatty liver disease. IBD medical consequences include also systemic complications, associated with the extra gastrointestinal manifestations' occurrence.

*Corresponding author: Matgorzata Szczuko, Department of Biochemistry and Human Nutrition, Pomeranian Medical University in Szczecin, Poland, E-mail: malgorzata.szczuko@pum.edu.pl Justyna Kikut: Department of Biochemistry and Human Nutrition, Pomeranian Medical University in Szczecin, Poland Nina Konecka: Department of Applied Neurocognitivistic, Pomeranian Medical University in Szczecin, Poland

Maciej Ziętek: Department of Perinatology, Obstetrics and Gynecology Pomeranian Medical University in Szczecin, Poland
Keywords: IBD; CD; UC; inflammation; IBD pathogenesis.

\section{Epidemiology of inflammatory bowel diseases (IBD)}

Non-specific inflammatory bowel diseases (IBD) include Crohn's disease (CD) and ulcerative colitis (UC). These are diseases with unexplained etiology. A steady increase in the inflammatory bowel diseases incidence is recently observed. Last comparative population study in Asia found that the incidence of IBD [1] varied across Asia, ranging from 0.54 per 100,000 to 3.44 per 100,000 persons. In Australia, the incidence rate of IBD, CD and UC in the age standard (WHO World Standard Population) was 25.2, 16.5 and 7.6 / 100,000 / year, respectively [2]. In an IBD study based on the population in Australia published in year 2010 [3], the annual incidence rates were among the highest described in the literature: $23.5-36.7$ per 100,000 per year. The study published in 2009 [4] provided data on the prevalence of UC incidence of 64 / 100,000 and of CD incidence of 21/100,000 in Japan. According to population studies, the incidence of $\mathrm{CD}$ and UC in Europe is around $0.3 \%$. In addition, in $1 / 4$ of patients, symptoms of the disease are observed to occur continuously [5]. In Poland, due to the lack of epidemiological research in this field, it is difficult to determine the exact incidence of IBD. Studies conducted by Jakubowski et al. Based on national hospital records showed 4.2 new cases of CD and 12.8 new cases of UC per 100,000 population in year 2007. In addition, the number of new patients hospitalized because of CD increased significantly, especially in the youngest age groups [6]. According to the World Gastroenterology Organization (WGO), the occurrence of IBD is higher in cities when compared to rural areas and the highest incidence is observed to occur on the third decade of life. IBD, although mainly affecting adult populations, also appear in increasingly younger patients. WGO also reports that Crohn's disease in adult population is more common in women, while in children, an opposite correlation is 
observed. Characteristic symptoms include the digestive tract, i.e. diarrhea, abdominal pain, anal bleeding. However, parenteral symptoms may also occur, such as joints, eyes or skin disorders. CD disease covers the entire digestive tract, while UC is usually limited to the colon mucosa [7].

\section{The mechanism of inflammation IBD}

Intestinal inflammation is a physiological process, the occurrence of which is necessary as a defense response reaction of the organism. Inflammation can be caused by internal factors associated with the body cells and by external factors, which include infections and exposures to inflammatory agents. The main purpose of inflammatory response is to localize and eliminate the injurious internal and external agents, as well as to protect tissues against their further destructive effect [8].

Pro-inflammatory cytokines include interleukin $1,2,6,7,8$, tumor necrosis factor $\alpha$ (TNF- $\alpha$ ), interferon $y$ (IFN-y) [9]. The cells of the immune system, epithelial layer cells and blood vessels endothelium are capable of producing compounds belonging to the cytokine group. They affect the growth and cell differentiation, and regulate the immune response by affecting proliferation, differentiation, $\mathrm{B}$ and $\mathrm{T}$ lymphocytes activation, monocytes, apoptosis and oxidative processes stimulation. Cytokines may have dual pro- or anti-inflammatory effects. The anti-inflammatory activity is demonstrated by interleukin 4, 10, 13, interferon $\alpha$ (IFN- $\alpha$ ) and beta-tumor growth factor (TGF- $\beta$ ) [10]. Elevated tumor necrosis factor (TNF) levels are strongly associated with the development of inflammatory diseases, including inflammatory bowel diseases [9,11,12].

The Crohn's disease associated inflammatory reaction is the result of abnormal Th1 cell response, with increased levels of IFN-y, IL-12 and TNF- $\alpha$ in suffering patients. Th1 and Th17 are involved in the production of pro-inflammatory cytokines and their uncontrolled proliferation is associated with development of IBD [13]. A significant effect of the IL-23 / IL-17 pathway has been demonstrated in the course of intestinal inflammation. The Th17 lymphocytes are associated with IBD induction on a way of secretion of pro-inflammatory cytokine IL-17. In contrast, the dendritic cells produced cytokine IL-23 affects the cells of the congenital immune system, thus contributing to the inflammation. In addition, IL-23 supports both the Th17 proliferation and maintenance [14].
Also, macrophages participate in inflammatory reactions by producing cytokines such as TNF- $\alpha$, IL-1 $\alpha$, IL-1 $\beta$, IL- 6 and nitric oxide which belongs to the proinflammatory mediators [15]. Although inflammation is considered as an organism physiological reaction, it can damage, when uncontrolled, the body's own tissues [16].

Via the cyclooxygenase and lipoxygenase pathways in which arachidonic acid is the substrate, eicosanoids and other lipid mediators are formed. Their activity is influenced by the type of PUFA from which they come. EPA and DHA are efficiently transformed into bioactive antiinflammatory metabolites, i.e. resolvins and maresins, protegrins and lipoxins. Resolvines, maresins, protegrins and lipoxins affect the acceleration of the inflammation quenching [17]. Pro-inflammatory mediators include leukotrienes and prostaglandins that are formed in course of transformation of the omega 3 pathway. It has been shown that the occurrence of quenching metabolites derived from DHA, was impaired in the presence of mucous membrane inflammation when compared to Crohn's disease remission state. Iincreased eicosanoids production derived from EPA and DHA may suppress disease processes and their insufficient quantities may maintain the inflammatory process [18]. In patients with inflammatory bowel disease elevated amounts of selected eicosanoids, ie prostaglandins 2 (PGE2), prostaglandins D2 (PGD2), thromboxane B2 (TXB2), leukotriene B4 (LTB4) and 5-, 12-, 15-HETE [19] were observed. Therefore, patients' EPA and DHA supplementation seems to be mandatory.

\section{Factors predisposing to IBD occurrence}

\section{Genetic factors}

Genetic and environmental factors create the immunological base for IBD development [20]. The main genes associated with Crohn's include: NOD2 / CARD15, ATG16L1 and IRGM genes. In addition, the Interleukin-23/Th17 pathways play an important role in the mechanism of both inflammatory bowel diseases. The UC and CD associated genes in the L23-Th17 pathway, include IL-23R (interleukin-23 receptor), IL-12B and STAT3 [21]. Binding of $I L 23$ by IL23R results in activation of the pathway that promotes an inflammation and regulates adaptive immune response [22]. The presence of NOD2 / CARD 15 genes' polymorphisms has probably the most important significance in the $\mathrm{CD}$ occurrence. This gene 
is located on the chromosome 16, and its product is an intracellular receptor belonging to a PRR (Pattern Recognition Receptor) family. The NOD 2 protein is a pattern recognition receptor for bacterial motifs, which along with TNF- $\alpha$ and TNF- $y$ cytokines affects regulation of the NF-KB dependent proinflammatory factors and is involved in signaling within the immune system. In physiology, the activation of NOD2 / CARD1 gene is involved in recognizing and destruction of certain pathogenic bacteria in intestinal epithelial cells. In the $\mathrm{CD}$, this gene is altered as a result of mutation, so that it does not function correctly and leads to the weakening of the intestinal barrier function by supporting dysbiosis [23]. In addition, it promotes the development of a pathogenic gut flora in patients with CD. Patients with gene mutation are also characterized by a lower level of protective defensin. Gene expression in macrophages is regulated by bacteria belonging to Bacteroidetes and Firmicutes families, secreting n-butyrate [24]. In addition to the above-mentioned gene, over 160 genes related to the development of IBD have been discovered so far [7]. Genes related to the controlled catabolic process such is autophagy, i.e. ATG16L1 and IRGM, have also been identified. This process is particularly important as a resistance barrier to infections. Genes that have been identified so far, account for about $20-25 \%$ of heritability. However, so large number of already identified genes indicates their important role in the pathogenesis of IBD [25]. As Atg16L1 is Crohn's disease susceptibility gene that have a critical function in innate immune defense against bacteria, its identification facilitated better knowing the CD intestinal flora disorders [22]. ATG16L1 is recruited by the NOD2 gene, but when the gene is mutated, ATG161L is missing, leading to autophagy problems [26]. The SLC9A3 gene, which mutation is responsible for the occurrence of congenital diarrhea and inflammation, has also been identified. The defect of this gene leads to abnormal intake of sodium in the intestine [27].

\section{Dysbiosis}

Until recently, IBD were classified as autoimmune diseases, but today they seem to be associated with disorders related to the intestinal barrier - dysbiosis [7]. Apart from genetic factors, behavioral factors are also taken for consideration, such as: antibiotic therapy in early infancy, operative delivery by caesarean section and increased total fat intake in diet [28]. In highly developed countries, a higher incidence rate on IBD is observed and this fact also applies to children. During the first three years of a child's life, its microbiome is formed. In this critical time of infant's microbiome development, antibiotics are turned on, new food ingredients in the diet are introduced, as well as feeding with modified milk instead of natural feeding, which affects microbiota and lead to its disorders [29].

Intestinal microflora component changes are observed in children with Crohn's disease. It is confirmed the fact in progressive number of scientific researches, that changes in intestinal microflora contribute to the occurrence of inflammation in the intestine tissue, and the severity of dysbiosis correlates with the severity of inflammatory reaction. It is observed a growing restriction of Firmicutes, Faecalibacterium and Roseburie contrary to the increase in the growth of Proteobacteria, Enteriobacteraceae and Ruminococcus gnavus [30]. Another study conducted on a group of 90 persons aged under 22, being in active stage of Crohn's disease, has shown a reduced number of species such as Prevotella, Eubacterium, Odoribacter, Akkermansia, Roseburia, Parabacteroides, Alistipes, Coprococcus, Dorea, and Ruminococcus whilean increased assemblage of Escherichia, Klebsiella, Enterococcus was observed and Veillonella [31]. Escherichia coli living in the gastrointestinal tract belongs to gram negative bacteria. However, there are E. coli strains producing harmful toxins and subsequently having noxious influence on the host organism.

Enteritis promotes the development of pathogenic strains of E. coli, which have an ability to regulate their own metabolism and obtain the necessary nutrients. It has been demonstrated that the deficiency of anti-inflammatory immunoglobulin A, which inhibits the adhesion and invasion of bacteria in the intestine, correlates with high E. coli colonies level. Immunoglobulin A deficiency may also facilitate a direct contact of bacteria with epithelium, which can lead to inflammatory mediators' activation [32]. In patients with Crohn's disease, elevated antibodies concentrations against E. coli have been observed. An E. coli types analysis showed, that those developing in $\mathrm{CD}$ patients are belong to groups $\mathrm{B}$ and $\mathrm{D}$, while commensal strains are mostly belong to group A [33].

Another study found higher levels of E. coli in UC and CD patients, but no statistically significant differences to healthy control group have been proved. Also the proportions between Lactobacillus spp and Bifidobacterium spp were reduced in both UC and CD patients, however, the obtained results were comparable to the control group. Significant differences were demonstrated in the Bacteroides spp culture grow in an active phase of $\mathrm{CD}$ and $\mathrm{UC}$ disease as well as in remission, when compared to the control group [34]. 


\section{Smoking}

In Crohn's disease, higher cigarette smoke carbon dioxide concentrations can lead to ischemic changes and chronic ulceration [35]. In a large cohort study involving women, it was noted that both previous and current smoking can significantly increase the risk of Crohn's disease. In turn, in ulcerative colitis patients, quitting smoking was associated with an increased risk of disease recurrence and the current smoking did not affect the disease. Nevertheless, a smoking in the past could have influenced the occurrence of UC [36]. In ulcerative colitis, smoking promotes a milder course of the disease, including rarer hospitalization and lower variability of drugs use. In patients suffering Crohn's disease, it has been shown that smokers had a 50\% higher risk of exacerbating the disease compared to persons who did never smoke. Furthermore, smoking can lower the therapeutic effectiveness during exacerbations, especially it weakens efficacy of infliximab treatment [37].

\section{Environmental pollution}

One of the possible factors favoring the development of IBD may be an environmental pollution. Urban development contributes to heavy metals accumulation, among others aluminum. Particularly large amounts of aluminum are observed to be found in water and the air. The rise of processed food intake in western diet provides also large amounts of this element into human organism. It has been shown that $40 \%$ of consumed aluminum accumulates in the gut. Experimental studies in mice have shown that the aluminum intake increased bacterial translocation, chronic inflammation process and markedly impaired intestinal wound healing [38].

\section{Nutritional factors}

\section{Western diet}

Western diet is characterized by animal fat, protein high content and fiber deficiency. It has been pointed that such a diet is strongly associated with the IBD pathogenesis. In addition, high intake of carbohydrates, including simple sugars, promotes reproduction of bacteria in the intestine [39]. The over consumption of processed food in the Western diet is constantly observed. It has been also shown that excessive consumption of meat products is associated with an increased risk of CD and UC incidence. Furthermore, low intake of vegetables and fruits may affect the development of IBD [40]. The use of a diet rich in both fat and sugar cause dysbiosis with marked growth of bacterial populations: Bacteroides spp. and Rumminococcus [41]. Another study showed a significant decrease in the acetate, butyrate and propionate concentration in mice subjected to above mentioned diet [42].

Western diet is also rich in salt $(\mathrm{NaCl})$. It has been demonstrated, that high salt intake in the diet positively correlates with the proinflammatory cytokines presence such as IL-17, IL-6 and IL-23 [43]. High NaCl concentrations have been observed to activate macrophages throughout the lipopolysaccharide stimulation. A significant increase in TNF and nitric oxide synthesis was noticed. Therefore, excessive salt intake may lead to pro-inflammatory activation of the immune system [44]. Experimental mice studies have shown that excessive sodium consumption leads to an exacerbation of chronic colitis in the colon [43]. In another experimental mice study, it has been proved that even a slight increase in salt intake supports IL-23R expression and Th17 differentiation as well [45].

\section{Natural ingredients of the diet - gluten}

Gluten is a protein found in cereals, in wheat it occurs in form of gliadin, in life - as a secalin, in barley - as hordein and as avenin in oats. It is largely used as a food additive, among others in order to obtain a better dough structure or as a cheaper substitute for animal protein in the production of sausages. Wheat is treated as grain, which consumption leads to gastrointestinal disorder symptoms [46]. In recent years, gluten-free diet has become very popular among people who haven't had celiac disease diagnosis. In the USA, it is estimated that a gluten-free diet is used by up to $0.5 \%$ of the population without diagnosed celiac disease [47]. Many symptoms that are associated with gluten consumption, e.g. abdominal pains or bloating, may also occur in course of inflammatory bowel diseases. In a study conducted in 314 IBD patients, $38.8 \%$ of them reported a reduced disease recurrence as a result of gluten-free diet introduction, while $23.6 \%$ of patients reported a reduce of medicines doses, used for disease control and treatment [47]. Similarly, in a further study involving 102 patients with IBD, up to $25 \%$ of them reported sensitivity to gluten [48]. It seems that due to gluten content increase in diet (filler in meats, increased consumption of bread and pasta and the consumption of tetraploid wheat) even in persons which are not predisposed to gluten allergies, 
the gastrointestinal tract disorders and disturbances may occur [49]. A separate issue is changing the traditional recipes of baking bread, where a consumption of bread baked on yeast instead of sourdough increases the risk of IBD [50].

\section{Natural ingredients of the diet - lactose}

Lactose is a disaccharide which is composed of glucose and galactose molecule. The highest lactase activity, an enzyme digesting lactose, is observed during infancy, after passing which her digestive capacity decreases [51]. Patients with Crohn's disease are exposed to secondary lactose intolerance, caused by lactase reduced concentration in the duodenal mucosa layer during exacerbation. In addition, lactose is digested in the intestinal villi in which the lactase is located. Therefore, persons with inflammation involving villi and mucosal layer damage are more likely to experience intolerance [52]. In a study of 165 patients suffering from Crohn's disease, $25.5 \%$ of them had an adverse reaction associated with milk products consumption, half of whom have generated a chronic reaction. In addition, $6.7 \%$ of patients were diagnosed with lactose intolerance [52]. However, it is estimated that in the CD population, up to $40-70 \%$ of patients may experience lactose intolerance [53].

\section{Food additives}

\section{Phosphates}

Phosphates are essential components needed for the development of skeleton and intracellular signal transduction pathways. It is also a component of food additives. A Sugihara et al. experimental rats study showed, that high dietary phosphate intake promotes intestinal inflammatory process by increasing free radicals' production. The inflammation level has been dose dependent on phosphorus administered to rats. The NFkB activation and histological tissue structure changes were also observed [54].

\section{Nanomolecules}

Nanomolecules, or very small insoluble molecules, may have a destructive effect on the intestines tissue. The nanomolecules include titanium dioxide, which is used not only in the chemical industry but can be also added to food as a white pigment (chewing gum, mayonnaise). Such molecules have an ability to increase cytokine responses to lipopolysaccharide (LPS) [55]. In addition, nanomolecules can be absorbed by $M$ cells in Peyer's patches of the intestine, thus impairing the function of macrophages and enhancing inflammatory activity [56]. In addition, the Western diet provides large amounts of such molecules to the organism [55].

\section{Emulsifiers}

Emulsifiers caused changes in the mice microflora by increasing lipopolysaccharide and flagellin protein, which led to inflammation. It has been also shown that such chronic dysbiosis is adequate for colon carcinogenesis promotion. It has been also noticed that the emulsifiers' induced inflammation does not present any histopathological features of inflammation but only causes low-grade gut inflammation [57].

\section{Carrageenan}

The carrageenan types are traditionally classified as the following three classes: kappa, iota and lambda. The last one is less likely to form a gel structure but gives high viscosity and is soluble in cold water. Carrageenan is used as a food additive to increase solubility and improve food texture. It is also a good substitute for fat. Carrageenans are effective ingredients, widely used in the food industry, among others, baby food, dietetic food, ice cream, yoghurt and many more [58]. Carrageenan includes a family of sulphate polysaccharides derived from seaweed, and its use as a food additive has increased in the last 50 years. The carrageenan administration with water to guinea pigs caused the appearance of human-like ulcers in UC, in the entire study group. In another study in mice, rats and rabbits, ulcerative lesions with polyps as well as symptoms such as weight loss or diarrhea were demonstrated. In addition, animals that were given carrageenan developed both acute, intermediate and chronic inflammatory reactions [59]. The study of Wei et al. conducted in mice treated with kappa carrageenan have shown the activation of proinflammatory cytokines such as IL-2, IL-6, and TNF- $\alpha$, while the level of inflammation quenching cytokine IL-10, was reduced [60]. 


\section{Carboxymethylcellulose (CMC)}

Carboxymethylcellulose (CMC) is derived from cellulose. Due toits low price, itis often used during food production. It is characterized by thickening and emulsifying properties. It is especially used to produce candies, chewing gums, ketchups and baked goods [59]. A study in IL-10 deficient mice, that received a carboxymethylcellulose solution showed, that CMC enhances bacterial overgrowth in these animals [61].

\section{Maltodextrin (MDX)}

In a study in which mice diet has been enriched with a 5\% solution of maltodextrin (MDX) after the dextran sodium sulfate (DSS) or indomethacin administration, they were characterized by a much more severe inflammatory reaction in the intestine. In addition, it is worth noting that a 5\% solution of maltodextrin is often observed in infant formula milk. MDX induces cellular stress, which leads to mucin secretion reduction. This results in an increased risk of intestinal colonization by bacterial pathogens, increased intestinal damage and higher ulcers incidence [62].

\section{Medical consequences and IBD complications}

\section{Anxiety and depressive disorders}

Persons with chronic diseases, including IBD, are more likely to experience both anxiety and depression. One of the reasons for mood depression appearance may be insufficient response to treatment, and thus reduced quality of life [63]. In addition, depression occurs in young people with UC and CD much more often than in the peer control group, and parents of children with IBD are at a higher risk of depression [64]. Long-lasting, chronic stress and pro-inflammatory cytokines on a path of pituitary corticotropin secretion, activate the hypothalamicpituitary-adrenal (HPA) axis. In a further step, the adrenocorticotropic hormone is cascade-activated, followed by adrenal stress hormone secretion - cortisol. It is the HPA axis disorder that is related to the occurrence of depression [65]. Although cytokines are large molecules, they can cross the blood-brain barrier. In the brain, cytokines affect the metabolism of serotonin, dopamine and corticoliberin activation, which are associated with the onset of depression [66]. In a study conducted by
Byrne et al. on 327 patients with IBD, 25.8\% of subjects had depression and $21.1 \%$ had anxiety. In addition, 31.8\% of patients were already treated psychiatrically, which shows an increased incidence of psychiatric disorders in persons suffering for chronic diseases [63]. Other studies also confirm the twofold higher prevalence of anxiety in patients with IBD, when compared to those without established inflammatory bowel disease [67].

\section{Multisystem complications}

Many patients suffering from IBD develop systemic complications. It is estimated that approximately $25-40 \%$ of patients with $\mathrm{CD}$ manifest symptoms coming from outside the gastrointestinal tract [68]. The parenteral complications can be divided into two groups, the first of them are diseases occurring mainly during periods of exacerbation (iritis, inflammation of large joints, erythema nodosum), the second group are diseases that occur independently of the underlying disease ( liver and bile ducts complications, ankylosing spondylitis) [69]. In addition, the most common parenteral symptoms include osteopenia, osteoporosis and fatty liver [68]. The mechanism of the occurrence of complications is not precisely understood, it is assumed that genetic and immunological factors are involved [70].

Osteoporosis and osteopenia are characterized by reduced bone mineral density. These are significant clinical problems in the group of IBD patients, resulting in a poorer quality of life and growth disorders among children and adolescents. There are many factors determining their development, however, they often present as a complication of long-term glucocorticoid therapy. In addition, intestinal absorption disorders conditioned by inflammatory processes affect the vitamins deficiencies, especially the fat-soluble (A, D, E, K) and calcium. Studies shown that calcium intake in patients' diet suffering from IBD is much smaller in comparison to healthy patients [71], which has also negative impact on calcium utilization and economy in the body.

Another disease entity coexisting with IBD is a steatotic liver disorder: non-alcoholic fatty liver disease (NAFLD). The factors that influence the occurrence of NAFLD in patients with IBD include altered intestinal permeability, dysbiosis, and chronic inflammatory response [72]. In addition, researches demonstrate existence of common mechanisms for the development of inflammatory bowel diseases and NAFLD. The immune system significant role should be pointed here, especially when regarding to the Th1 and Th2 cells response, which are of integral 
importance in the pathogenesis of not only CD but also NAFLD. The relative Th1 cytokines excess or deficit may affect the liver steatosis process.

In addition, natural killer (NK) cells through Th1 cells participation can release active substances such as porphorin and granzyme, which can directly damage the liver. Furthermore, intestinal microflora composition disorders may result in increased gut permeability due to intestinal bacteria activity and their metabolic products as well. Bacterial endotoxin (lipopolysaccharide) in combination with the lipopolysaccharide binding protein (LBP) is transporting into the circulatory system and connects to the TLR4 receptor. Next, the TNF- $\alpha$, IL- 6 and reactive oxygen species are released. As a result, lipid peroxidation occurs with NFLD promoting and liver fibrosis development [73].

\section{References}

1. Ng SC, Tang W, Ching JY, Wong M, Chow CM, Hui AJ, et al. Incidence and phenotype of inflammatory bowel disease based on results from the Asia-Pacific Crohn's and colitis epidemiology study. Gastroenterology 2013;145:158-65.

2. Gearry RB, Richardson A, Frampton CMA, Collett JA, Burt MJ, Chapman BA, et al. High incidence of Crohn's disease in Canterbury, New Zealand: results of an epidemiologic study. Inflamm Bowel Dis 2006;12:936-43.

3. Wilson J, Hair C, Knight R, Catto-Smith A, Bell S, Kamm M, et al. High incidence of inflammatory bowel disease in Australia: a prospective population-based Australian incidence study. Inflamm Bowel Dis 2010;16:1550-6.

4. Asakura K, Nishiwaki Y, Inoue N, Hibi T, Watanabe M, Takebayashi T. Prevalence of ulcerative colitis and Crohn's disease in Japan. J Gastroenterol 2009;44:659-65.

5. Burisch J., Jess T, Martinato M., Lakatos PL; ECCO -EpiCom.: The burden of inflammatory bowel disease in Europe. J Crohns Colitis, 2013;7(4):322-37.

6. Jakubowski A, Bartnik W, Kraszewska E i wsp. Trendy hospitalizacji z powodu nieswoistych chorób zapalnych jelit w Polsce. Gastroenterologia Polska 2010; 17: 50.

7. Wehkamp J., Götz M., Herrlinger K., Steurer W., Stange E.: Inflammatory Bowel Disease. Crohn's disease and ulcerative colitis. Dtsch Arztebl Int., 2016; 113(5): 72-82.

8. Nasef N.A., Mehta S., Ferguson L.R.: Susceptibility to chronic inflammation: an update. Arch Toxicol. 2017 Mar;91(3):11311141.

9. Javed, Q.: Clinical Implications of Tumor Necrosis Factor-Alpha, Interleukin-6 and Resistin in Coronary Artery Disease. World Journal of Cardiovascular Diseases, 2014; 4: 416-421

10. Kaźmierczak E., Jabłecka A.: Zapalne czynniki predykcyjne choroby wieńcowej. Nadciśnienie tętnicze, 2009;12:4.

11. Sudoł-Szopińska I., KontnyE., MaślińskiW., Prochorec-Sobieszek M., Kwiatkowska B., i wsp.: Patogeneza reumatoidalnego zapalenia stawów w badaniach radiologicznych. Część I:
Powstawanie nacieków zapalnych w błonie maziowej. Journal of Ultrasonography 2012; 12: 202-213

12. Grotesky T., Dirisina R., Sinh P., Mittal N., Managlia E., Williams D., Posca D., Ryu H., Katzman R., Barrett T.:p53 Mediates TNFInduced Epithelial Cell Apoptosis in IBD. The American Journal of Pathology .2012; 181(4): 1306-1315

13. Alhassan Mohammed H., Mirshafiey A., Vahedi H., Hemmasi G., Moussavi Nasl Khameneh A., Parastouei K., et all: Immunoregulation of Inflammatory and Inhibitory Cytokines by Vitamin D3 in Patients with Inflammatory Bowel Diseases. Scand J Immunol. 2017 Jun;85(6):386-394.

14. Cătană C.S., Berindan Neagoe I., Cozma V., Magdaş C., Tăbăran F., Dumitraşcu D.L.: Contribution of the IL-17/IL-23 axis to the pathogenesis of inflammatory bowel disease. World J Gastroenterol. 2015 May 21;21(19):5823-30.

15. Ko W.K., Lee S.H., Kim S.J., Jo M.J., Kumar H., Han I.B., et all: Anti-inflammatory effects of ursodeoxycholic acid by lipopolysaccharide-stimulated inflammatory responses in RAW 264.7 macrophages. PLoS One. 2017; 12(6): e0180673.

16. Allam-Ndoul B., Guénard F., Barbier O., Vohl M.C.: Effect of n-3 fatty acids on the expression of inflammatory genes in THP-1 macrophages. Lipids Health Dis. 2016; 15: 69.

17. Molfino A., Amabile M.I., Monti M., Muscaritoli M.: Omega-3 Polyunsaturated Fatty Acids in Critical Illness: AntiInflammatory, Proresolving, or Both? Oxid Med Cell Longev. 2017; 2017: 5987082.

18. Scaioli E., Liverani E., Belluzzi A.: The Imbalance between n-6/n-3 Polyunsaturated Fatty Acids and Inflammatory Bowel Disease: A Comprehensive Review and Future Therapeutic Perspectives. Int J Mol Sci., 2017; 18(12): 2619.

19. Rodríguez-Lagunas M., Ferrer R., Moreno J: Effect of eicosapentaenoic acid-derived prostaglandin E3 on intestinal epithelial barrier function. Prostaglandins Leukot Essent Fatty Acids., 2013;88(5):339-45.

20. Zatorski H., Sataga M., Zielińska M., Fichna J.: Czynniki genetyczne w patogenezie, przebiegu i leczeniu nieswoistych chorób zapalnych jelit. Postępy Hig Med., 2015;69:335-344.

21. Wejman J., Bartnik W.: Atlas kliniczno-patologiczny nieswoistych chorób zapalnych jelit. Wyd. 1. Poznań: Wydaw: Termedia; 2011. ISBN: 978-83-62138-62-3.

22. de Lange KM., Barrett JC.: Understanding inflammatory bowel disease via immunogenetics. J Autoimmun. 2015 Nov;64:91100.

23. Konturek S.J., red.: Gastroenterologia i hepatologia kliniczna. Warszawa: Wydaw. Lekarskie PZWL;2006. ISBN 83-200-3188-5.

24. Lauro M.L., Burch J.M., Grimes C.L.: The Effect of NOD2 on the Microbiota in Crohn's Disease. Curr Opin Biotechnol. 2016 Aug; 40: 97-102.

25. Zhang YZ., Li YY.: Inflammatory bowel disease: pathogenesis. World J Gastroenterol. 2014 Jan 7;20(1):91-9.

26. lida T., Onodera K., Nakase H.: Role of autophagy in the pathogenesis of inflammatory bowel disease. World J Gastroenterol. 2017 Mar 21; 23(11): 1944-1953.

27. Uhlig HH., Muise AM.: Clinical Genomics in Inflammatory Bowel Disease. Trends Genet. 2017 Sep;33(9):629-641.

28. Rosen M., MSCl, Dhawan A., MBBS, MSPH, Saeed S.: Inflammatory Bowel Disease in Children and Adolescents. JAMA Pediatr., 2015; 169(11): 1053-1060. 
29. Bernstein C.N.: Review article: changes in the epidemiology of inflammatory bowel disease-clues for aetiology. Aliment Pharmacol Ther. 2017 Nov;46(10):911-919.

30. Brusaferroa A., Cavallia E., Farinellia E., Cozzalia R., Principib N., Esposito S.: Gut dysbiosis and paediatric Crohn's disease. J Infect. 2018 Oct 15. pii: S0163-4453(18)30308-6.

31. Lewis JD., Chen EZ., Baldassano R.N., Otley A.R., Griffiths A.M., Lee D., et all: Inflammation, Antibiotics, and Diet as Environmental Stressors of the Gut Microbiome in Pediatric Crohn's Disease. Cell Host Microbe. 2015 Oct 14;18(4):489-500.

32. Khan S., Imran A., Malik A., Chaudhary AA., Rub A., et all: Bacterial imbalance and gut pathologies: Association and contribution of E. coli in inflammatory bowel disease. Crit Rev Clin Lab Sci. 2018 Oct 29:1-17

33. Tawfik A., Flanagan P.K., Campbell B.J.: Escherichia coli-host macrophage interactions in the pathogenesis of inflammatory bowel disease. World J Gastroenterol. 2014 Jul 21; 20(27): 87518763.

34. Vrakas S., Mountzouris K.C., Michalopoulos G., Karamanolis G., Papatheodoridis G., Tzathas C., et all: Intestinal Bacteria Composition and Translocation of Bacteria in Inflammatory Bowel Disease. PLoS One. 2017; 12(1): e0170034.

35. Abegunde AT., Muhammad BH., Bhatti O., Ali T.: Environmental risk factors for inflammatory bowel diseases: Evidence based literature review. World J Gastroenterol. 2016 Jul 21; 22(27): 6296-6317.

36. Higuchi LM., Khalili H., Chan AT., Richter JM., Bousvaros A., Fuchs CS.: A Prospective Study of Cigarette Smoking and the Risk of Inflammatory Bowel Disease in Women. Am J Gastroenterol. 2012 Sep; 107(9): 1399-1406.

37. Cosnes J.: Tobacco and IBD: relevance in the understanding of disease mechanisms and clinical practice. Best Pract Res Clin Gastroenterol. 2004 Jun;18(3):481-96.

38. Pineton de Chambrun G., Body-Malapel M., Frey-Wagner I., Djouina M., Deknuydt F., Atrott K., et all: Aluminum enhances inflammation and decreases mucosal healing in experimental colitis in mice. Mucosal Immunol. 2014 May;7(3):589-601.

39. Dixon LJ., Kabi A., Nickerson KP., McDonald C.: Combinatorial effects of diet and genetics on inflammatory bowel disease pathogenesis. Inflamm Bowel Dis. 2015 Apr;21(4):912-22.

40. Dolan KT., Chang EB.: Diet, gut microbes, and the pathogenesis of inflammatory bowel diseases. Mol Nutr Food Res. 2017 Jan;61(1).

41. Martinez-Medina M., Denizot J., Dreux N., Robin F., Billard E., Bonnet R., et all: Western diet induces dysbiosis with increased E coli in CEABAC10 mice, alters host barrier function favouring AIEC colonisation. Gut. 2014 Jan;63(1):116-24.

42. Agus A., Denizot J., Thévenot J., Martinez-Medina M., Massier S., Sauvanet P.: Western diet induces a shift in microbiota composition enhancing susceptibility to Adherent-Invasive E. coli infection and intestinal inflammation. Sci Rep. 2016 Jan 8;6:19032.

43. Tubbs AL., Liu B., Rogers TD., Sartor RB., Miao EA.: Dietary Salt Exacerbates Experimental Colitis. J Immunol. 2017 Aug 1;199(3):1051-1059.

44. Schatz V., Neubert P., Schröder A., Binger K., Gebhard M., Müller DN., et all: Elementary immunology: $\mathrm{Na}+$ as a regulator of immunity. Pediatr Nephrol. 2017 Feb;32(2):201-210.
45. Wu C., Yosef N., Thalhamer T., Zhu C., Xiao S., Kishi Y., et all: Induction of pathogenic Th17 cells by inducible salt sensing kinase SGK1. Nature. 2013 Apr 25; 496(7446): 513-517.

46. Biesiekierski JR.: What is gluten? J Gastroenterol Hepatol. 2017 Mar;32 Suppl 1:78-81.

47. Herfarth HH., Martin CF., Sandler RS., Kappelman MD., Long MD.: Prevalence of a gluten-free diet and improvement of clinical symptoms in patients with inflammatory bowel diseases. Inflamm Bowel Dis. 2014 Jul;20(7):1194-7.

48. Limketkai BN., Sepulveda R., Hing T., Shah ND., Choe M. Limsui D., Shah S.: Prevalence and factors associated with gluten sensitivity in inflammatory bowel disease. Scand J Gastroenterol. 2018 Feb;53(2):147-151.

49. Molberg O, Uhlen AK, Jensen T, Flaete NS, Fleckenstein B, ArentzHansen H, Raki M, Lundin KE, Sollid LM. Mapping of gluten T-cell epitopes in the bread wheat ancestors: implications for celiac disease. Gastroenterology. 2005;128(2):393-401.

50. Laatikainen R, Koskenpato J, Hongisto SM, Loponen J Poussa T, Huang X, Sontag-Strohm T, Salmenkari H, Korpela R. Pilot Study: Comparison of Sourdough Wheat Bread and YeastFermented Wheat Bread in Individuals with Wheat Sensitivity and Irritable Bowel Syndrome. Nutrients. 2017;9(11).

51. Deng Y., Misselwitz B., Dai N., Fox M.: Lactose Intolerance in Adults: Biological Mechanism and Dietary Management. Nutrients. 2015 Sep 18;7(9):8020-35.

52. Nolan-Clark D., Tapsell LC., Hu R., Han DY., Ferguson LR.: Effects of dairy products on crohn's disease symptoms are influenced by fat content and disease location but not lactose content or disease activity status in a New Zealand population. J Am Diet Assoc. 2011 Aug;111(8):1165-72.

53. von Tirpitz C., Kohn C., Steinkamp M., Geerling I., Maier V., Möller P., et all: Lactose intolerance in active Crohn's disease: clinical value of duodenal lactase analysis. J Clin Gastroenterol. 2002 Jan;34(1):49-53.

54. Sugihara K., Masuda M., Nakao M., Abuduli M., Imi Y., Oda N., et all: Dietary phosphate exacerbates intestinal inflammation in experimental colitis. J Clin Biochem Nutr. 2017 Sep;61(2):91-99.

55. Richman E., Rhodes JM.: Review article: evidence-based dietary advice for patients with inflammatory bowel disease. Aliment Pharmacol Ther. 2013 Nov;38(10):1156-71.

56. Butler M., Boyle JJ., Powell JJ., Playford RJ., Ghosh S.: Dietary microparticles implicated in Crohn's disease can impair macrophage phagocytic activity and act as adjuvants in the presence of bacterial stimuli. Inflamm Res. 2007 Sep;56(9):35361.

57. Viennois E., Merlin D., Gewirtz AT., Chassaing B.: Dietary Emulsifier-Induced Low-Grade Inflammation Promotes Colon Carcinogenesis. Cancer Res. 2017 Jan 1;77(1):27-40.

58. Tobacman JK.: Review of harmful gastrointestinal effects of carrageenan in animal experiments. Environ Health Perspect. 2001 Oct; 109(10): 983-994.

59. Martino JV., Van Limbergen J., Cahill LE.: The Role of Carrageenan and Carboxymethylcellulose in the Development of Intestinal Inflammation. Front Pediatr. 2017 May 1;5:96.

60. Wei W., Feng W., Xin G., Tingting N., Zhanghe Z., Haimin C., Xiaojun Y.: Enhanced effect of $\mathrm{k}$-carrageenan on TNBS-induced inflammation in mice. Int Immunopharmacol. 2016 Oct;39:218228.

61. Swidsinski A., Ung V., Sydora BC., Loening-Baucke V., Doerffel Y., Verstraelen H., Fedorak RN.: Bacterial overgrowth and 
inflammation of small intestine after carboxymethylcellulose ingestion in genetically susceptible mice. Inflamm Bowel Dis. 2009 Mar;15(3):359-64.

62. Laudisi F., Di Fusco D., Dinallo V., Stolfi C., Di Grazia A., Marafini I., et all: The Food Additive Maltodextrin Promotes Endoplasmic Reticulum Stress-Driven Mucus Depletion and Exacerbates Intestinal Inflammation. Cell Mol Gastroenterol Hepatol. 2018.

63. Byrne G., Rosenfeld G., Leung Y., Qian H., Raudzus J., Nunez C., Bressler B.: Prevalence of Anxiety and Depression in Patients with Inflammatory Bowel Disease. Can J Gastroenterol Hepatol. 2017;2017:6496727

64. Levy RL., van Tilburg MA., Langer SL., Romano JM., Walker LS., Mancl LA., et all: Effects of a Cognitive Behavioral Therapy Intervention Trial to Improve Disease Outcomes in Children with Inflammatory Bowel Disease. Inflamm Bowel Dis. 2016 Sep;22(9):2134-48.

65. Breit S., Kupferberg A., Rogler G., Hasler G.: Vagus Nerve as Modulator of the Brain-Gut Axis in Psychiatric and Inflammatory Disorders. Front Psychiatry. 2018; 9: 44.

66. Raison CL., Capuron L., Miller AH.: Cytokines sing the blues: inflammation and the pathogenesis of depression. Trends Immunol. 2006 Jan;27(1):24-31.

67. Fuller-Thomson E., Lateef R., Sulman J.: Robust Association Between Inflammatory Bowel Disease and Generalized Anxiety Disorder: Findings from a Nationally Representative Canadian Study. Inflamm Bowel Dis. 2015 Oct;21(10):2341-8.
68. Nowaczyk M., Żołądek M., Philavong P., Linke K., ŁykowskaSzuber L., Krela-Kaźmierczak I.: Zaćma jako powikłanie przewlekłej steroidoterapii stosowanej w leczeniu choroby Leśniowskiego-Crohna. Forum Medycyny Rodzinnej, 2016;10(6):314-318.

69. Bartnik W.: Wytyczne postępowania w nieswoistych chorobach zapalnych jelit. Przegląd Gastroenterologiczny, 2007;2(5):215229.

70. Manganelli C., Turco S., Balestrazzi E. Ophthalmological aspects of IBD. Eur. Rev. Med. Pharmacol. Sci. 2009; 13: 11-13.

71. Philavong P., Żołądek M., Nowaczyk M., Linke K., ŁykowskaSzuber L., Krela-Kaźmierczak I: Osteoporoza posteroidowa w chorobie Leśniowskiego-Crohna. Gastroenterologia Kliniczna, 2016;8(1):36-41.

72. Chao CY., Battat R., Khoury A., Sebastiani G., Bessissow T.: Co-existence of non-alcoholic fatty liver disease and inflammatory bowel disease: A review article. World J Gastroenterol, 2016;22(34):7727-7734.

73. Dejian L., Chao L., Chaohui Y.: High incidence of non-alcoholic fatty liver disease in patients with Crohn's disease but nor ulcerative colitis. Int J Clin Exp Pathol, 2017;10(10):10633=10639. 